\title{
Expression of LOX-1 in human mesangial cells is increased by Ox-LDL and IL-1 $\beta$ treatment
}

\author{
YINGHUI DENG, NA LIN, LEIYUN WU, QAING JIA and HUA LIU \\ Department of Nephrology, Xuanwu Hospital, Capital Medical University, Beijing 100053, P.R. China
}

Received May 31, 2016; Accepted March 31, 2017

DOI: $10.3892 /$ etm.2017.4950

\begin{abstract}
The present study aimed to determine whether the expression of lectin-like oxidized LDL receptor 1 (LOX-1) could be induced by oxidized low-density lipoprotein (Ox-LDL) and interleukin $1 \beta$ (IL-1 $\beta$ ) in human mesangial cells (HMCs). Oil Red O staining was used to observe the uptake of Ox-LDL by HMCs stimulated with IL-1 $\beta$, and reverse transcription-quantitative polymerase chain reaction analysis and western blotting were used to examine the expression of LOX-1 in HMC following Ox-LDL and IL-1 $\beta$ treatment. Uptake of Ox-LDL by HMCs was upregulated upon stimulation with IL-1 $\beta$. Furthermore, Ox-LDL (10-40 $\mu \mathrm{g} / \mathrm{ml})$ treatment induced LOX-1 mRNA and protein expression in a dose-dependent manner. In addition, when HMCs were treated with IL- $1 \beta$ and Ox-LDL, the expression of LOX-1 was enhanced further. These results indicated that inhibiting LOX-1 expression or inhibiting the Ox-LDL/LOX-1 signaling axis may be a potential novel method for treating renal disease.
\end{abstract}

\section{Introduction}

Various types of renal disease are characterized by an abnormal lipid metabolism, with hyperlipidemia being associated with the progression of renal disease. Previous studies have identified that glomerular sclerosis and atherosclerosis exhibit similar pathological changes and underlying pathophysiological mechanisms (1-3). Atherosclerosis is associated with inflammation, while kidney disease often occurs in a microinflammatory state, which suggests that inflammation and lipid metabolism mediates the progression of glomerular sclerosis and kidney disease at the cellular level (1-3).

Lectin-like oxidized LDL receptor 1 (LOX-1) is the receptor for oxidized low-density lipoprotein (Ox-LDL). The

Correspondence to: Dr Hua Liu, Department of Nephrology, Xuanwu Hospital, Capital Medical University, 45 Changchun Street, Beijing 100053, P.R. China

E-mail: liuhuaxw@sina.com

Key words: oxidized low-density lipoprotein, human mesangial cell, lectin-like oxidized LDL receptor 1 , interleukin $1 \beta$ specific binding of Ox-LDL to LOX-1 causes endothelial dysfunction and serves a role in the formation of atherosclerotic plaques. Therefore, LOX-1 is a key factor in the occurrence and development of atherosclerosis (4). It has been revealed that the regulation of LOX-1 in human coronary artery endothelial cells by Ox-LDL was positively correlated with the concentration of Ox-LDL (5). However, the association between Ox-LDL and LOX-1 in mesangial cells remains unclear. LOX-1 expression in endothelial cells can be induced by a variety of proinflammatory cytokines (6), while the effects of interleukin $1 \beta$ (IL-1 $\beta$ ) on the Ox-LDL/LOX-1 axis is unclear. In the present study, the effect of Ox-LDL on the expression of LOX-1 in human glomerular mesangial cells was examined. In addition, the role of inflammation in this regulation was explored.

\section{Materials and methods}

Cell culture and identification. Human glomerular mesangial IP15 cell lines (HMCs; Renal Disease Center, Royal Free Hospital of England; London, UK) were cultured in RPMI-1640 medium supplemented with $10 \%$ fetal bovine serum (FBS; Gibco; Thermo Fisher Scientific, Inc., Waltham, $\mathrm{MA}, \mathrm{USA}$ ) at $37^{\circ} \mathrm{C}$ with $5 \% \mathrm{CO}_{2}$. The protein expression levels of actin, collagen IV, fibronectin, vimentin, cytokeratin and factor VIII were tested by an indirect immunofluorescence assay using kits for anti-collagen IV antibody (ab6586), anti- $\beta$ actin antibody (ab8227), anti-fibronectin antibody (ab2413), anti-vimentin antibody (ab137321), anti-wide spectrum cytokeratin antibody (ab9377) and anti-factor VIII antibody (ab203590; all Abcam, Cambridge, UK) according to the previous study (7).

Lipid staining. The HMCs $\left(1 \times 10^{6}\right.$ cells $\left./ \mathrm{ml}\right)$ were divided into IL- $1 \beta$ treatment $(5 \mathrm{ng} / \mathrm{ml}$ IL- $1 \beta+0.2 \%$ RPMI-1640), where cells were treated for $24 \mathrm{~h}$ at $37^{\circ} \mathrm{C}$, and control $(0.2 \%$ RPMI-1640) groups. The cells were subsequently treated with $40 \mu \mathrm{g} / \mathrm{ml} \mathrm{Ox}-\mathrm{LDL}$ and cultured for a further $24 \mathrm{~h}$. The cells were then stained with Oil Red $\mathrm{O}$ for $15 \mathrm{~min}$ at $37^{\circ} \mathrm{C}$ and observed under a light microscope.

Flow cytometry. Cells were treated with $2.5,5$ and $10 \mathrm{ng} / \mathrm{ml}$ IL-1 $\beta$ for $24 \mathrm{~h}$, respectively. The cells were also treated with IL-1 $\beta 5 \mathrm{ng} / \mathrm{ml}+$ Ox-LDL and IL-1 $\beta 5 \mathrm{ng} / \mathrm{ml}+\mathrm{LOX}-1$, respectively. The fluorescence values at $0,8,12$ and $24 \mathrm{~h}$ were 
detected using the flow cytometry method (8). Analysis was performed using BD FACSCalibur CELLQuest software version 3.0 (BD Biosciences; Franklin Lakes, NJ, USA).

Ox-LDL cytotoxicity assay. The HMCs were treated with different concentrations of Ox-LDL (0, 40, 80, 100, 120, 150 and $200 \mu \mathrm{g} / \mathrm{ml}$ ) for $24 \mathrm{~h}$ at $37^{\circ} \mathrm{C}$ and cultured in RPMI-1640 medium supplemented with $10 \% \mathrm{FBS}$ at $37^{\circ} \mathrm{C}$ with $5 \% \mathrm{CO}_{2}$ for $24 \mathrm{~h}$. Subsequently, morphological changes in the HMCs were observed under a phase-contrast microscope. The cells were then harvested and digested with trypsin. The cell debris was resuspended with PBS following centrifugation (120 x g for $5 \mathrm{~min}$ at room temperature) and the suspension was stained with trypan blue for $5 \mathrm{~min}$ at room temperature. The number of HMCs was counted in five randomly selected visual fields and the apoptosis rate was calculated as follows: Apoptosis rate $(\%)=$ (number of stained cells/total cell number) x 100. In addition, a lactate dehydrogenase $(\mathrm{LDH})$ release test was performed with an Pierce $^{\mathrm{TM}} \mathrm{LDH}$ Cytotoxicity Assay Kit (Pierce; Thermo Fischer Scientific, Inc., Waltham, MA, USA) according to the manufacturer's protocol. The optical density was measured at a $490-\mathrm{nm}$ wavelength with a microplate reader.

Reverse transcription-quantitative polymerase chain reaction $(R T-q P C R)$ analysis. The effects of different concentrations of Ox-LDL and IL- $1 \beta$ on LOX-1 mRNA expression were detected by RT-qPCR. HMCs were divided into the following groups randomly: Control (untreated); Ox-LDL $(10,20,40$ and $60 \mu \mathrm{g} / \mathrm{ml}$ Ox-LDL); $5 \mathrm{ng} / \mathrm{ml} \mathrm{IL-1 \beta ;} 40 \mu \mathrm{g} / \mathrm{ml}$ Ox-LDL + $5 \mathrm{ng} / \mathrm{ml} \mathrm{IL-1 \beta}$; and $60 \mu \mathrm{g} / \mathrm{ml} \mathrm{Ox-LDL}+5 \mathrm{ng} / \mathrm{ml}$ IL-1 $\beta$. Cells were treated with Ox-LDL and IL-1 $\beta$ for $24 \mathrm{~h}$ at $37^{\circ} \mathrm{C}$. Total RNA was extracted from the cells using an E.Z.N.A. ${ }^{\circledR}$ Total RNA kit I (Omega Bio-Tek, Inc., Norcross, GA, USA) according to the manufacturer's protocol. cDNA were synthesized from this RNA using PrimeScript RT master mix (Takara Bio, Inc. Otsu, Japan) following the manufacturer's protocol. Subsequently, qPCR was performed using an ABI 7500 Fast Real-Time PCR system (Applied Biosystems; Thermo Fisher Scientific, Inc.) with SYBR Premix Ex Taq II (Takara Bio, Inc.) master mix. $10 \mu \mathrm{M}$ primers and $40 \mathrm{ng}$ cDNA was used. The thermocycling conditions were as follows: Denaturation at $95^{\circ} \mathrm{C}$ for $30 \mathrm{sec}$; 40 amplification cycles at $95^{\circ} \mathrm{C}$ for $10 \mathrm{sec}$; and $60^{\circ} \mathrm{C}$ for $30 \mathrm{sec}$. GAPD was used as the control. The primer sequences were as follows: LOX-1 forward, 5'-ACAGAGGCCATTCCGAAATCA-3' and reverse, 5'-GGTAGAGTCTGGAGATGGACCACA-3'; and GAPDH forward, 5'-GCACCGTCAAGGCTGAGAAC-3' and reverse, 5'-ATGGTGGTGAAGACGCCAGT-3'. The quantification method used was the $2^{-\Delta \Delta \mathrm{Cq}}$ method as described previously (9).

Western blotting. LOX-1 protein expression was detected via western blotting. Briefly, $5 \times 10^{5}$ cells/well were seeded into 6-well plates with RPMI-1640 medium containing 10\% FBS and cultured for $24 \mathrm{~h}$ at $37^{\circ} \mathrm{C}$. The medium was subsequently replaced with RPMI-1640 without serum and the cells were cultured for a further $12 \mathrm{~h}$. The RPMI-1640 with serum was then changed, and the cells were treated with different concentrations of Ox-LDL and IL-1 $\beta$ [Ox-LDL (10, 20, 40

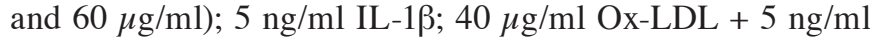
IL-1 $\beta$; and $60 \mu \mathrm{g} / \mathrm{ml} \mathrm{Ox-LDL}+5 \mathrm{ng} / \mathrm{ml} \mathrm{IL-1 \beta}$ respectively] and cultured for $24 \mathrm{~h}$. The cells were washed twice with cold PBS and lysed with radioimmunoprecipitation assay lysis buffer (Biovision Inc., Palo Alto, CA, USA) for 25 min on ice. The cell lysates were centrifuged at $180 \mathrm{x} \mathrm{g}$ for $10 \mathrm{~min}$ at $4^{\circ} \mathrm{C}$ and protein concentration was measured using the Bradford protein assay (10). Total protein $(50 \mu \mathrm{g})$ was separated on a $12 \%$ gel using SDS-PAGE. Proteins were transferred onto polyvinylidene difluoride membranes (EMD Millipore, Billerica, MA, USA), which were blocked with 5\% non-fat milk in Tris-buffered saline with Tween-20 [10 mM Tris- $\mathrm{HCl}$ (pH 8.0), $150 \mathrm{mM} \mathrm{NaCl}$ and $0.1 \%$ Tween-20] for $2 \mathrm{~h}$, and then incubated with the primary anti-LOX 1 antibody (dilution 1:1,000; ab60178; Abcam; Cambridge, MA, USA), anti- $\beta$-actin antibody (dilution 1:5,000; ab8227; Abcam). at $4^{\circ} \mathrm{C}$ overnight. Following this, the membranes were incubated with horseradish peroxidase-conjugated secondary anti-Rabbit IgG (dilution 1:10,000; ab191866; Abcam) at room temperature for $1 \mathrm{~h}$. Protein bands were then detected using an enhanced chemiluminescence detection kit (K820-500; Biovision Inc., Palo Alto, CA, USA). ImageJ software (version 1.37; National Institutes of Health; Bethesda, MD, USA) was used to quantify the results.

Statistical analysis. All data are presented as the mean \pm standard deviation. Statistical analysis was performed using SPSS software (version 17.0; SPSS, Inc., Chicago, IL, USA). Differences between the experimental groups were analyzed by one-way analysis of the variance and a post hoc Kruskal-Wallis test. $\mathrm{P}<0.05$ was considered to indicate a statistically significant difference.

\section{Results}

$I L-1 \beta$ promotes the uptake of $O x-L D L$ by $H M C s$. The results of Oil Red $\mathrm{O}$ staining revealed notably more lipid staining around the nucleus of HMCs treated with IL-1 $\beta$ compared with HMCs in the control group (Fig. 1). This suggests that IL-1 $\beta$ enhances the uptake of Ox-LDL by HMCs.

IL-1 $\beta$ enhances the uptake of $O x-L D L$ by HMCs in a dose-and time-dependent manner. The results of immunofluorescence measured using the flow cytometry method after the HMCs were treated with $2.5,5$ or $10 \mathrm{ng} / \mathrm{ml} \mathrm{IL-1} \beta$ for $24 \mathrm{~h}$ demonstrated that the average fluorescence reached a peak value in the $10 \mathrm{ng} / \mathrm{ml} \mathrm{IL}-1 \beta$ treatment group (Table I). Effects of $5 \mathrm{ng} / \mathrm{ml}$ IL-1 $\beta$ on uptaking Ox-LDL by HMCs at different times were shown in Table II. Effects of Anti-LOX-1 antibody were shown in Table III. These indicated that IL-1 $\beta$ enhances the uptake of Ox-LDL by HMCs in a dose- and time-dependent manner.

A high Ox-LDL concentration increases HMC apoptosis. There was no notable difference in the morphology of HMCs treated with 40-120 $\mu \mathrm{g} / \mathrm{ml}$ Ox-LDL-treated and the control group (data not shown). However, floating and dead cells were observed in the 150 and $200 \mu \mathrm{g} / \mathrm{ml} \mathrm{Ox}$-LDL-treated groups. Furthermore, the results of trypan blue staining and the LDH release test revealed that apoptosis rate of the HMCs increased 
Table I. Effects of different concentrations of IL-1 and oxidized low-density lipoprotein on human glomerular mesangial cells intake during $24 \mathrm{~h}$.

\begin{tabular}{lc}
\hline $\mathrm{IL}-1 \beta(\mathrm{ng} / \mathrm{ml})$ & $\begin{array}{c}\text { Average fluorescence } \\
\text { value per unit area }(\mathrm{n}=3)\end{array}$ \\
\hline Control & $6.74 \pm 0.35$ \\
2.5 & $13.7 \pm 0.46^{\mathrm{a}}$ \\
5 & $38.0 \pm 1.03^{\mathrm{a}}$ \\
10 & $49.6 \pm 1.22^{\mathrm{a}}$ \\
\hline
\end{tabular}

${ }^{\mathrm{a}} \mathrm{P}<0.01$ vs. control. Data are presented as the mean \pm standard deviation. IL, interleukin.

Table II. Effects of $5 \mathrm{ng} / \mathrm{ml} \mathrm{IL-11 \beta}$ on the uptake oxidized low-density lipoprotein by human glomerular mesangial cells at different times.

Time (h)

Average fluorescence

\begin{tabular}{ll}
\hline Control & $7.69 \pm 0.32$ \\
8 & $17.3 \pm 0.51^{\mathrm{a}}$ \\
12 & $37.8 \pm 0.97^{\mathrm{a}}$ \\
24 & $41.9 \pm 1.05^{\mathrm{a}}$ \\
\hline
\end{tabular}

${ }^{\mathrm{a}} \mathrm{P}<0.01$ vs. control. Data are presented as the mean \pm standard deviation.

Table III. Effects of anti-LOX-1 antibody.

Average fluorescence

Treatment value per unit area $(n=3)$

\section{Control}

$5 \mathrm{ng} / \mathrm{ml} \mathrm{IL-1 \beta}+$ anti-LOX-1

$5 \mathrm{ng} / \mathrm{ml} \mathrm{IL-} \beta$

${ }^{\mathrm{a}} \mathrm{P}<0.05$ vs. IL-1 $\beta$ group; ${ }^{\mathrm{b}} \mathrm{P}<0.01$ vs. Control. Data are presented as the mean \pm standard deviation. IL, interleukin; LOX-I, lectin-like oxidized LDL receptor 1.

after treatment with $>120 \mu \mathrm{g} / \mathrm{ml}$ Ox-LDL concentration; treatment with $<120 \mu \mathrm{g} / \mathrm{ml}$ Ox-LDL resulted in an apoptosis rate of $<5 \%$ (Fig. 2).

Effect of $O x-L D L$ and $I L-1 \beta$ on the expression of $L O X-1$. Ox-LDL treatment (10-40 $\mu \mathrm{g} / \mathrm{m}$;) significantly increased the expression of LOX-1 mRNA in HMCs in a dose-dependent manner ( $\mathrm{P}<0.01$ vs. the control group; Fig. 3). Combining 40 or $60 \mu \mathrm{g} / \mathrm{ml} \mathrm{Ox}-\mathrm{LDL}$ treatment with $5 \mathrm{ng} / \mathrm{ml}$ IL-1 $\beta$ significantly increased the expression of LOX-1 compared with Ox-LDL treatment alone $(\mathrm{P}<0.01$; Fig. 4). The western blotting results
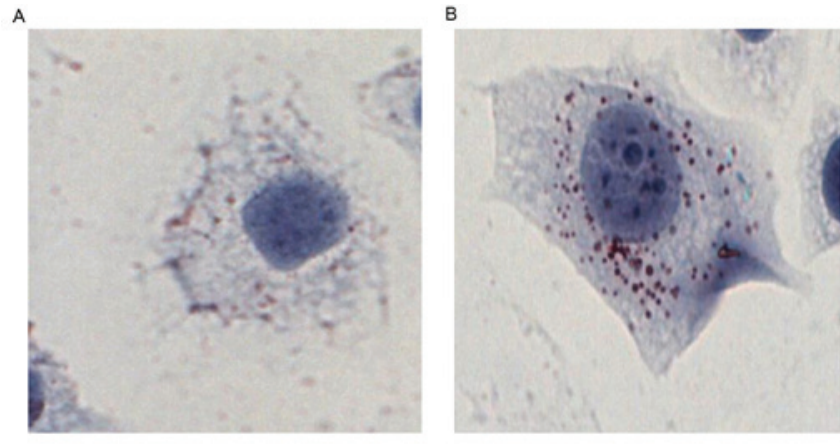

Figure 1. IL-1 $\beta$ promotes the uptake of oxidized low-density lipoprotein by human glomerular mesangial cells. Oil Red O staining of the (A) untreated control and (B) $5 \mathrm{ng} / \mathrm{ml} \mathrm{IL-1 \beta}$ treatment groups (magnification, $\mathrm{x} 400$ ). IL, interleukin.

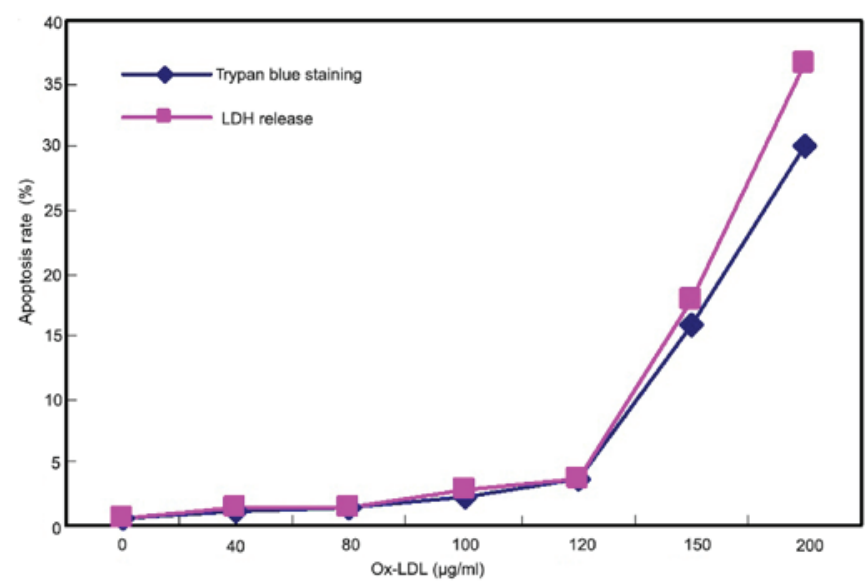

Figure 2. Ox-LDL promotes HMC apoptosis. Results of trypan blue staining and lactate dehydrogenase release test on HMCs treated with Ox-LDL $(0-200 \mu \mathrm{g} / \mathrm{ml})$. HMCs, human glomerular mesangial cells; Ox-LDL, oxidized low-density lipoprotein.

revealed similar increases in LOX-1 protein expression following Ox-LDL or Ox-LDL + IL-1 $\beta$ treatment (Figs. 5 and 6).

\section{Discussion}

Hyperlipidemia is a common clinical manifestation of renal disease and abnormal lipid metabolism is associated with the progression of renal disease (11). Hyperlipidemia is an independent risk factor for the occurrence and development of glomerular sclerosis; however, plasma cholesterol levels do not necessarily correlate with the degree of glomerular sclerosis $(12,13)$. Glomerular sclerosis and atherosclerosis exhibit similar pathological changes and underlying pathophysiological mechanisms (14), and inflammation serves a key role in the development of glomerular sclerosis.

The presence of macrophage-derived foam cells is an important feature of early atherosclerosis, while the infiltration of the foam cells derived from mesangial cells in the kidney is a characteristic of glomerular sclerosis (15). Furthermore, mesangial and vascular smooth muscle cells possess several similar properties, including secretory matrix and cell shrinkage, and can also uptake Ox-LDL. Therefore, it is thought that mesangial cells are associated with lipid-mediated renal damage (16). The 


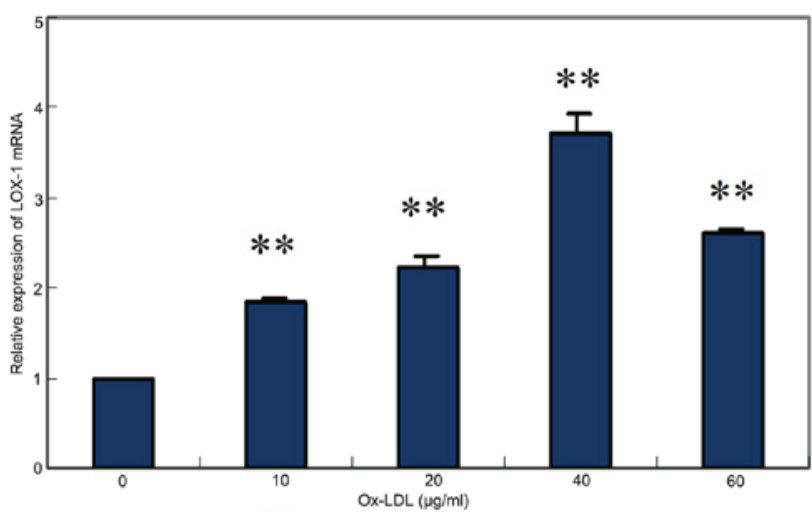

Figure 3. Ox-LDL increases the expression of LOX-1 mRNA in human glomerular mesangial cells. Ox-LDL mRNA expression was measured by reverse transcription-quantitative polymerase chain reaction relative to GADPH. ${ }^{* *} \mathrm{P}<0.01$ vs. the control group. Ox-LDL, oxidized low-density lipoprotein; LOX-1, lectin-like oxidized LDL receptor 1.

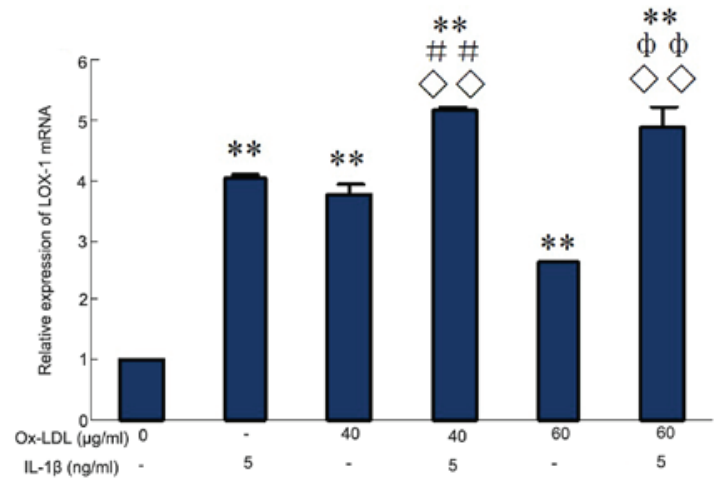

Figure 4. Ox-LDL and IL-1 $\beta$ combined treatment significantly increases the expression of LOX-1 mRNA in human glomerular mesangial cells compared with Ox-LDL treatment alone. Ox-LDL mRNA expression was measured by reverse transcription-quantitative polymerase chain reaction relative to GADPH. ${ }^{* *} \mathrm{P}<0.01$ vs. the control group; ${ }^{\# \#} \mathrm{P}<0.01$ vs. $40 \mu \mathrm{g}$ Ox-LDL alone treatment; ${ }^{\phi \phi} \mathrm{P}<0.01$ vs. $60 \mu \mathrm{g}$ Ox-LDL alone treatment; ${ }^{\diamond 0} \mathrm{P}<0.01$ vs. $5 \mathrm{ng} / \mathrm{ml}$ IL-1 $\beta$ alone treatment. Ox-LDL, oxidized low-density lipoprotein; IL, interleukin; LOX-1, lectin-like oxidized LDL receptor 1.

present study revealed that HMCs expressed the LOX-1 receptor. Finally, a previous study indicated higher levels of expression of adhesion and inflammatory factors promoted monocyte macrophage accumulation and engulfed the Ox-LDL, which participated in the formation of atherosclerotic plaque (17).

LOX-1 is a key contributing factor to the occurrence and development of atherosclerosis, and to the progression of chronic kidney disease (18). Additionally, an increase in LOX-1 expression in the renal artery is associated with intimal hyperplasia and renal fibrosis. Furthermore, anti-LOX-1 therapy can reverse the increase of kidney damage caused by diabetes, oxidative stress and leukocyte infiltration, and can improve the renal microvascular bed (19). Increased expression of LOX-1 in the kidney of type 2 diabetic rats has been demonstrated to aggravate the injury of renal interstitial nephritis, which suggests that it is important in the occurrence and development of diabetic nephropathy (20).

Previous studies have revealed that Ox-LDL exerts regulation on the LOX-1 receptor in human coronary artery endothelial cells $(1,2)$, and mesangial cells could uptake

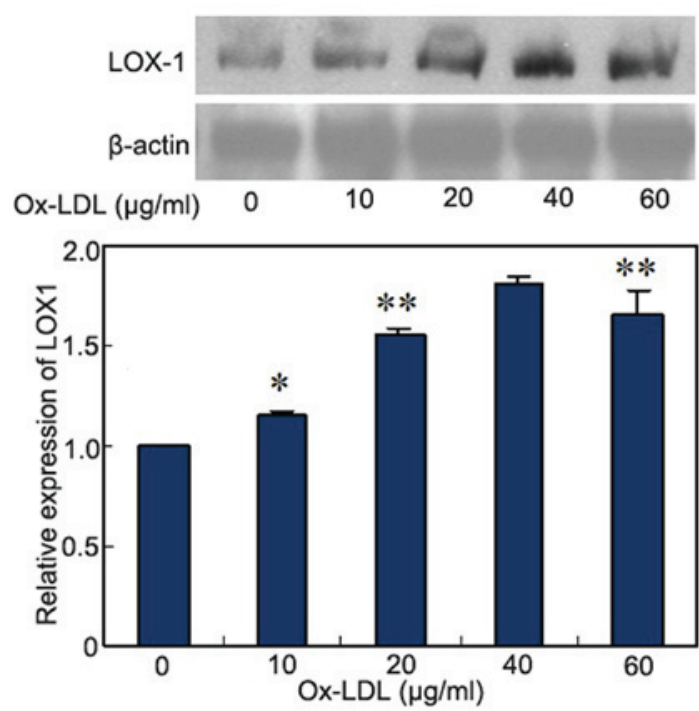

Figure 5. Ox-LDL increases the expression of LOX-1 protein. Ox-LDL protein expression was measured by western blotting followed by densitometry. ${ }^{* *} \mathrm{P}<0.01$ and ${ }^{*} \mathrm{P}<0.05$ vs. the control group. Ox-LDL, oxidized low-density lipoprotein; LOX-1, lectin-like oxidized LDL receptor 1.

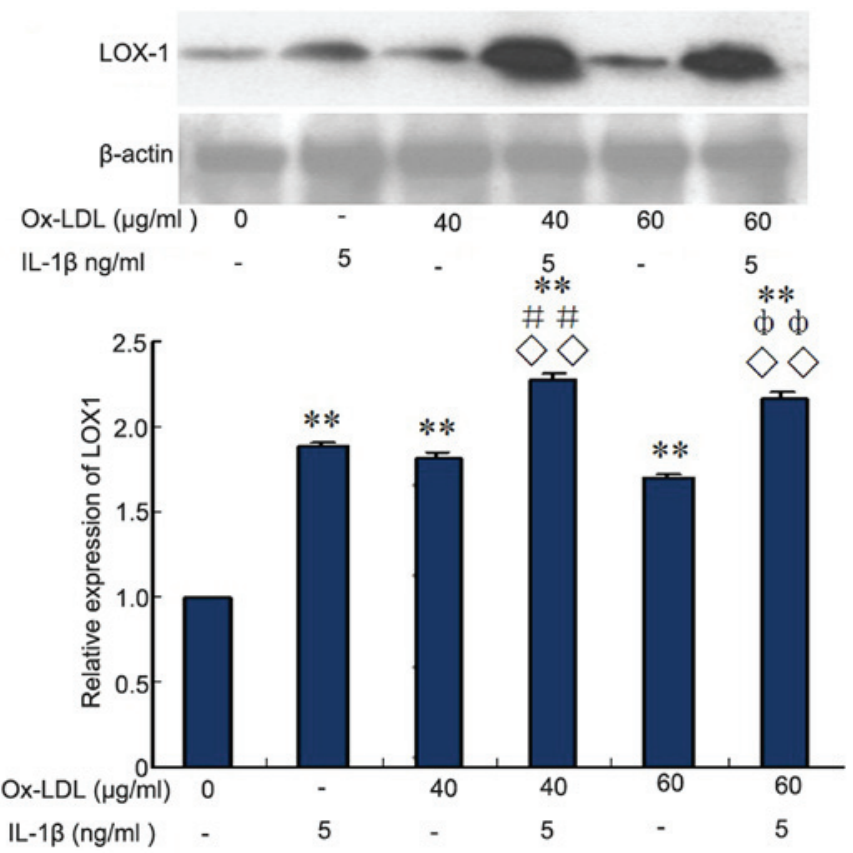

Figure 6. Ox-LDL and IL-1 $\beta$ combined treatment significantly increases the expression of LOX-1 protein in human glomerular mesangial cells compared with Ox-LDL treatment alone. Ox-LDL protein expression was measured by western blotting followed by densitometry. ${ }^{* *} \mathrm{P}<0.01$ vs. the control group; ${ }^{\# \#} \mathrm{P}<0.01$ vs. $40 \mu \mathrm{g}$ Ox-LDL alone treatment; ${ }^{\phi} \mathrm{P}<0.01$ vs. $60 \mu \mathrm{g}$ Ox-LDL alone treatment; ${ }^{\diamond} \mathrm{P}<0.01$ vs. $5 \mathrm{ng} / \mathrm{ml} \mathrm{IL-} 1 \beta$ alone treatment. Ox-LDL, oxidized low-density lipoprotein; IL, interleukin; LOX-1, lectin-like oxidized LDL receptor 1.

Ox-LDL through the LOX-1 receptor signaling pathway, which suggests that the LOX-1 signaling pathway may underlie the pathogenesis of lipid metabolism disorders (21). The present study revealed that $10-40 \mu \mathrm{g} / \mathrm{ml}$ Ox-LDL could significantly upregulate LOX-1 mRNA and protein expression in HMCs in a dose-dependent manner. Furthermore, LOX-1 expression was increased further by $5 \mathrm{ng} / \mathrm{ml} \mathrm{IL-1} \beta$ and Ox-LDL 
cotreatment. Additionally, IL-1 $\beta$ changed the regulation of Ox-LDL n LOX-1 and promoted the uptake of Ox-LDL by HMCs. Thus, inflammation is a risk factor for the progression of atherosclerosis and nephropathy.

In conclusion, the present study revealed that IL-1 $\beta$ accelerated the uptake of Ox-LDL by HMCs by altering the regulation of Ox-LDL on its receptor LOX-1. These results indicate that inhibiting LOX-1 expression or inhibiting the Ox-LDL/LOX-1 signaling axis are potential novel treatments for renal disease.

\section{References}

1. Ruan XZ, Varghese Z, Powis SH and Moorhead JF: Dysregulation of LDL receptor under the influence of inflammatory cytokines: A new pathway for foam cell formation. Kidney Int 60: 1716-1725, 2001.

2. Keane WF, Tomassini JE and Neff DR: Lipid abnormalities in patients with chronic kidney disease: Implications for the pathophysiology of atherosclerosis. J Atheroscler Thromb 20: 123-133, 2013.

3. Ma KL, Ruan XZ, Powis SH, Chen Y, Moorhead JF and Varghese Z: Inflammatory stress exacerbates lipid accumulation in hepatic cells and fatty livers of apolipoprotein $\mathrm{E}$ knockout mice. Hepatology 48: 770-781, 2008.

4. Morawietz H: LOX-1 receptor as a novel target in endothelial dysfunction and atherosclerosis. Dtsch Med Wochenschr 135: 308-312, 2010 (In German).

5. Li D and Mehta JL: Upregulation of endothelial receptor for oxidized LDL (LOX-1) by oxidized LDL and implications in apoptosis of human coronary artery endothelial cells: Evidence from use of antisense LOX-1 mRNA and chemical inhibitors. Arterioscler Thromb Vasc Biol 20: 1116-1122, 2000.

6. Kelly KJ, Wu P, Patterson CE, Temm C and Dominguez JH: LOX-1 and inflammation: A new mechanism for renal injury in obesity and diabetes. Am J Physiol Renal Physiol 294: F1136-F1145, 2008.

7. Mendes-Jorge L, Llombart C, Ramos D, López-Luppo M, Valença A, Nacher V, Navarro M, Carretero A, Méndez-Ferrer S Rodriguez-Baeza A and Ruberte J: Intercapillary bridging cells: Immunocytochemical characteristics of cells that connect blood vessels in the retina. Exp Eye Res 98: 79-87, 2012.

8. Schwartz C and Voehringer D: Identification of murine basophils by flow cytometry and histology. Methods Mol Biol 1192: 229-237, 2014.

9. Livak KJ and Schmittgen TD: Analysis of relative gene expression data using real-time quantitative PCR and the 2(-Delta Delta C(T)) method. Methods 25: 402-408, 2001.
10. Okutucu B, Dinçer A, Habib O and Zihnioglu F: Comparison of five methods for determination of total plasma protein concentration. J Biochem Biophys Methods 70: 709-711, 2007.

11. Banach M, Aronow WS, Serban MC, Rysz J, Voroneanu L and Covic A: Lipids, blood pressure and kidney update 2015. Lipids Health Dis 14: 167, 2015.

12. Fang Q, Zou C, Zhong P, Lin F, Li W, Wang L, Zhang Y, Zheng C, Wang Y, Li X and Liang G: EGFR mediates hyperlipidemia-induced renal injury via regulating inflammation and oxidative stress: The detrimental role and mechanism of EGFR activation. Oncotarget 7: 24361-24373, 2016.

13. Song Y, Du C, Zhang W, Sun Y, Yang L, Cui C, Chi Y, Shou J, Zhou A, Wang J and Sun Y: A study on the association between hyperlipidemia and hypothyroidism and the response to TKIs in metastatic renal cell carcinoma. Asia Pac J Clin Oncol 12: 174-180, 2016.

14. Nagase M, Kaname S, Nagase T, Wang G, Ando K, Sawamura T and Fujita T: Expression of LOX-1, an oxidized low-density lipoprotein receptor, in experimental hypertensive glomerulosclerosis. J Am Soc Nephrol 11: 1826-1836, 2000.

15. Jefferson JA and Shankland SJ: The pathogenesis of focal segmental glomerulosclerosis. Adv Chronic Kidney Dis 21: 408-416, 2014.

16. Li E, Wang T, Wang F, Wang T, Sun LQ, Li L, Niu SH and Zhang JY: FGF21 protects against ox-LDL induced apoptosis through suppressing CHOP expression in THP1 macrophage derived foam cells. BMC Cardiovasc Disord 15: 80, 2015.

17. Twigg $\mathrm{MW}$, Freestone $\mathrm{K}$, Homer-Vanniasinkam $\mathrm{S}$ and Ponnambalam S: The LOX-1 scavenger receptor and its implications in the treatment of vascular disease. Cardiol Res Pract 2012: 632408, 2012.

18. Ishino S, Mukai T, Kume N, Asano D, Ogawa M, Kuge Y, Minami M, Kita T, Shiomi M and Saji H: Lectin-like oxidized LDL receptor-1 (LOX-1) expression is associated with atherosclerotic plaque instability-analysis in hypercholesterolemic rabbits. Atherosclerosis 195: 48-56, 2007.

19. Yamamoto N, Toyoda M, Abe M, Kobayashi T, Kobayashi K, Kato M, Miyauchi M, Kimura M, Umezono T and Suzuki D: Lectin-like oxidized LDL receptor-1 (LOX-1) expression in the tubulointerstitial area likely plays an important role in human diabetic nephropathy. Intern Med 48: 189-194, 2009.

20. Xu Y, Ruan S, Xie H and Lin J: Role of LOX-1 in Ang II-induced oxidative functional damage in renal tubular epithelial cells. Int J Mol Med 26: 679-690, 2010.

21. Ruan XZ, Moorhead JF, Fernando R, Wheeler DC, Powis SH and Varghese Z: PPAR agonists protect mesangial cells from interleukin 1beta-induced intracellular lipid accumulation by activating the ABCA1 cholesterol efflux pathway. J Am Soc Nephrol 14: 593-600, 2003. 